\title{
Combined Effects of the Continual Application of Composted Rice Straw and Chemical Fertilizer on Rice Yield under a Double Rice Cropping System in the Mekong Delta, Vietnam
}

\author{
Takeshi WATANABE ${ }^{1,2 *}$, Hong Man LUU ${ }^{3}$, Ngoc Han NGUYEN ${ }^{3}$, \\ Osamu ITO $^{4}$ and Kazuyuki INUBUSHI ${ }^{5}$ \\ ${ }^{1}$ Crop, Livestock and Environment Division, Japan International Research Center for Agricultural \\ Sciences (Tsukuba, Ibaraki 305-8686, Japan) \\ ${ }^{2}$ Horticulture Division, Chiba University (Matsudo, Chiba 271-8510, Japan) \\ ${ }^{3}$ Soil Microbiology Group, Cuu Long Delta Rice Research Institute (Thoi Lai District, Cantho City, \\ Vietnam) \\ ${ }^{4}$ United Nations University (Shibuya ward, Tokyo 150-8925, Japan) \\ ${ }^{5}$ Graduate School of Horticulture, Chiba University (Matsudo, Chiba 271-8510, Japan)
}

\begin{abstract}
We conducted a 12-year field experiment to study the combined effects of rice straw compost and chemical fertilizer application on a double rice cropping system in the Mekong Delta, Vietnam and established 7 treatments using a randomized block design with 3 replications. We calculated the yields of treatments relative to those of conventionally fertilized plots (i.e. with no added rice straw compost), and analyzed their annual trends. In the plots with rice straw compost, we observed a positive trend over 12 continuous wet cropping seasons. In comparison with conventional fertilization, the application of rice straw compost with reduced chemical fertilizer can maintain rice productivity over a longer period. We analyzed the nutrient status of the rice straw at harvest over 4 cropping seasons and observed that the Si concentration of the rice straw in conventionally fertilized plots was significantly lower than that in the plots where rice straw compost was applied. The N, P and Mg concentrations of the rice straw increased with the fertilizer application rate, while the concentrations of $\mathrm{K}, \mathrm{Ca}, \mathrm{Mn}, \mathrm{Fe}$, $\mathrm{Zn}$, and $\mathrm{Cu}$ did not differ significantly among treatments. Our results suggest that continuous removal of rice straw may reduce the $\mathrm{Si}$ availability in soil, thereby decreasing rice productivity. In addition, we verified that rice straw compost can be an effective source of silicon for paddy rice.
\end{abstract}

Discipline: Soils, fertilizers and plant nutrition

Additional key words: nutrient balance, silicon, soil fertility, sustainable land use

\section{Introduction}

The Mekong Delta is the largest rice-producing area in Vietnam. The region produces more than 18 million tons of rice annually ${ }^{6}$, which constitutes approximately half the country's total rice production. The soil organic matter content of the Mekong Delta is generally high ${ }^{11,13}$. In contrast to the Red River Delta in northern Vietnam, most farmers in the Mekong Delta cultivate rice (Oryza sativa) without manure or compost; moreover, farmers generally burn the rice straw, or remove it for use in mushroom cultivation, vegetable mulching, or cattle feeding. The intensification of land use, combined with a reduced supply of nutrient-laden sediment because of improved control of floodwater from the Mekong River, may exacerbate the decrease in soil fertility, hence the increasing importance of soil fertility management. Limited data exist regarding the long-term trends in soil fertility of the Mekong Delta ${ }^{14,19}$. To develop practical soil fertility management options for the region's rice farmers, it is essential to clarify the sustainability of conventional farming practice. If the current practice is unsustain-

This paper reports the results obtained in the JIRCAS research projects on "Development of sustainable farming system in the Mekong Delta" from 2000 to 2004, "Technology Development to Establish Good Soil Care (GSC) in the Tropics" from 2006 to 2011 , and "Development of agricultural technologies in developing regions to respond to climate change" in 2011, conducted in the experimental field of the Cuu Long Delta Rice Research Institute, Vietnam.

*Corresponding author: e-mail watatake@jircas.affrc.go.jp

Received 30 November 2012; accepted 16 January 2013. 
able, the reasons must be identified.

In the present study, we investigated the long-term effects of the continuous application of rice straw compost on the overall soil fertility status of a Mekong Delta alluvial soil $^{20,21}$. We also compared annual rice yield trends between plots fertilized with chemical fertilizer alone and those fertilized with a combination of rice straw compost (RSC) and chemical fertilizer. To evaluate the combined effects of RSC and chemical fertilizer application, we determined the nutrient content (N, P, K, Si, Ca, Mg, Mn, Fe, Zn, and Cu) of the rice straw. A nutrient imbalance has previously been shown to cause a reduction in yield ${ }^{4,23}$, and we postulated that manure and compost could potentially supply the required nutrients.

\section{Materials and methods}

\section{Experimental design}

We conducted our experiment in an experimental field at the Cuu Long Delta Rice Research Institute (CLRRI, Thoi Lai District, Can Tho City, Vietnam, $\left.10^{\circ} 08^{\prime} \mathrm{N}, 105^{\circ} 35^{\prime} \mathrm{E}\right)$. Long-term studies on the effects of rice straw compost application were initiated during the 2000 wet season ${ }^{20}$. The rice crop was cultivated twice per year, during the wet and dry seasons. The wet season crop was planted in April or May, followed by the dry season crop in November or December. The crop variety used, sowing method and seed application rate are summarized in Table 1.

Throughout the experiment, the rice variety OM4900 (growth duration of 95-100 days) was directly sown using a row seeder planting machine.

We established the following 7 treatments using a randomized block design with 3 replications:

(1) $\mathrm{F} 0 \mathrm{C}-$ (or control), 0:0:0 N: $\mathrm{P}_{2} \mathrm{O}_{5}: \mathrm{K}_{2} \mathrm{O}$

(2) $\mathrm{F} 0 \mathrm{C}+, \operatorname{RSC}\left(6 \mathrm{t} \mathrm{ha}^{-1}\right)$

(3) F40C-, 40\% NPK $\left(32: 12: 12\right.$ or $40: 12: 12 \mathrm{~N}: \mathrm{P}_{2} \mathrm{O}_{5}$ : $\left.\mathrm{K}_{2} \mathrm{O} \mathrm{kg} \mathrm{ha}{ }^{-1}\right)$

(4) $\mathrm{F} 40 \mathrm{C}+$, RSC $\left(6 \mathrm{t} \mathrm{ha}^{-1}\right)+40 \%$ NPK $(32: 12: 12$ or $\left.40: 12: 12 \mathrm{~N}: \mathrm{P}_{2} \mathrm{O}_{5}: \mathrm{K}_{2} \mathrm{O} \mathrm{kg} \mathrm{ha}{ }^{-1}\right)$

(5) F60C-, 60\% NPK (48:18:18 or $60: 18: 18 \mathrm{~N}: \mathrm{P}_{2} \mathrm{O}_{5}$ : $\mathrm{K}_{2} \mathrm{O} \mathrm{kg} \mathrm{ha}{ }^{-1}$ )
(6) $\mathrm{F} 60 \mathrm{C}+, \mathrm{RSC}\left(6 \mathrm{tha}^{-1}\right)+60 \%$ NPK $(48: 18: 18$ or $\left.60: 18: 18 \mathrm{~N}: \mathrm{P}_{2} \mathrm{O}_{5}: \mathrm{K}_{2} \mathrm{O} \mathrm{kg} \mathrm{ha}{ }^{-1}\right)$

(7) $\mathrm{F} 100 \mathrm{C}-, 100 \%$ inorganic fertilizer (wet season, 80:30:30 N: $\mathrm{P}_{2} \mathrm{O}_{5}: \mathrm{K}_{2} \mathrm{O} \mathrm{kg} \mathrm{ha-1}$; dry season, 100:30:30 N: $\mathrm{P}_{2} \mathrm{O}_{5}: \mathrm{K}_{2} \mathrm{O} \mathrm{kg} \mathrm{ha-1}$ )

Each plot covered an area of $30 \mathrm{~m}^{2}(5 \times 6 \mathrm{~m})$. Treatment F100C- was based on the conventional farming practice in the region. RSC (which was made only from the rice straw grown in the experimental field) and phosphorus (P) fertilizer (single superphosphate) were mixed into soil at the time of cultivation before sowing the rice seed. $\mathrm{N}$ fertilizer (urea) was split into three applications: equivalent thirds broadcast at 10, 20 and 30 days respectively after sowing (DAS). The potassium (K) fertilizer (potassium chloride) was split into two applications: half of which was broadcast at $10 \mathrm{DAS}$ and the remainder at $30 \mathrm{DAS}$. Treatments F0C-, $\mathrm{F} 0 \mathrm{C}+, \mathrm{F} 40 \mathrm{C}+, \mathrm{F} 60 \mathrm{C}+$, and $\mathrm{F} 100-$ were initiated during the 2000 wet season. Before the 2009/2010 dry season, the $\mathrm{F} 40 \mathrm{C}-$ and $\mathrm{F} 60 \mathrm{C}$ - treatment plots were fertilized with RSC $\left(6 \mathrm{tha}^{-1}\right)+\mathrm{NPK}\left(16: 6: 6\right.$ or 20:6:6 N: $\left.\mathrm{P}_{2} \mathrm{O}_{5}: \mathrm{K}_{2} \mathrm{O} \mathrm{kg} \mathrm{ha}^{-1}\right)$ and $\operatorname{RSC}\left(6 \mathrm{tha}^{-1}\right)+\mathrm{NPK}\left(64: 24: 24\right.$ or 80:24:24 N: $\mathrm{P}_{2} \mathrm{O}_{5}: \mathrm{K}_{2} \mathrm{O} \mathrm{kg}$ $\left.\mathrm{ha}^{-1}\right)$, respectively. The field layout and experimental details, including the soil site characteristics, were described previously ${ }^{20}$. Rice straw was cut and removed from the field after harvest, while pest management practices followed the standard CLRRI practices.

\section{Yield measurement and statistical analysis of relative yield trends}

We determined the yields from the sampling area for harvest $(2.5 \times 2 \mathrm{~m})$ within each plot at harvest and counted the panicle number for four sampling areas (each $0.5 \times 0.5$ $\mathrm{m})$ within each plot at harvest. The spikelet per panicle, filled grain (\%) and 1000 grain weight was measured from 40 panicles randomly selected within each plot. The cultivars and sawing method changed during the experiment, meaning annual changes in yield could not be directly analyzed. To evaluate annual trends in rice yield, as affected by the crop varieties used and weather variables, we calculated the relative cropping yields using the following formula:

Table 1. Variety of the cultivated rice, the seeding rate and the sowing method

\begin{tabular}{cccc}
\hline \hline Duration $^{\dagger}$ & Variety & Seeding rate $\left(\mathrm{kg} \mathrm{ha}^{-1}\right)$ & Method of sowing \\
\hline 2000WS $\sim 2004 / 2005 \mathrm{DS}$ & IR64 & 200 & Broadcasting \\
2005 WS & IR64 & 150 & Broadcasting \\
2005/2006DS $\sim 2008 \mathrm{WS}$ & OM2517 & 100 & Row seeding \\
2008/2009DS $\sim 2011 \mathrm{WS}$ & OM4900 & 100 & Row seeding \\
\hline
\end{tabular}

$\dagger$ Rice was not cultivated in the dry season 2003/2004. $\ddagger$ Two treatments were changed from the dry season 2009/2010. WS, wet season; DS, dry season. 
Dry season 2009/2010
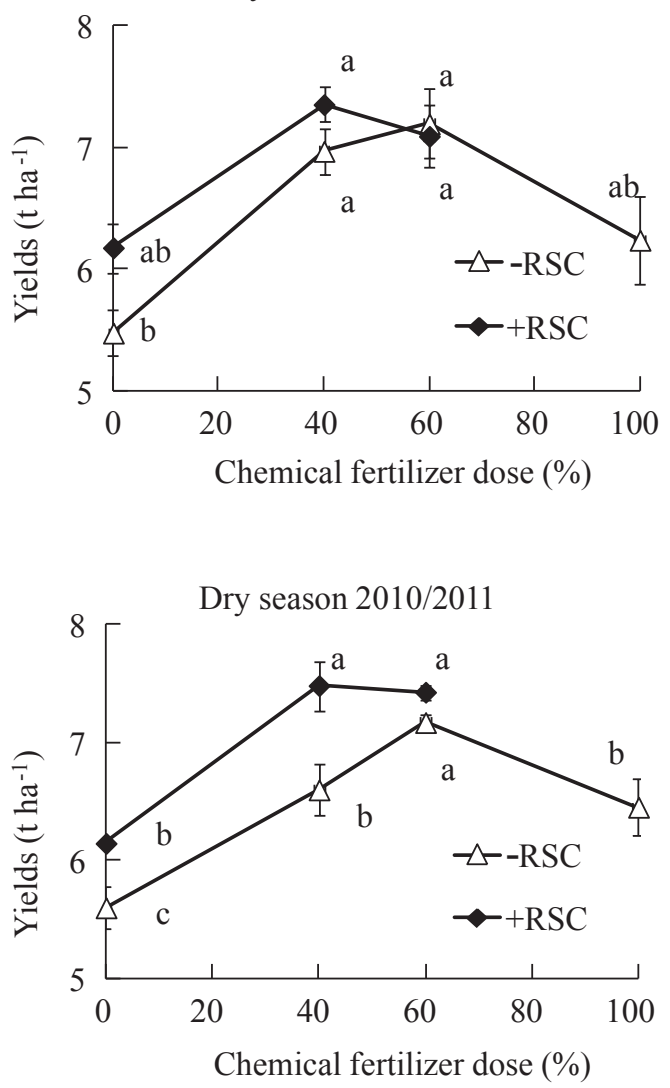

Wet season 2010
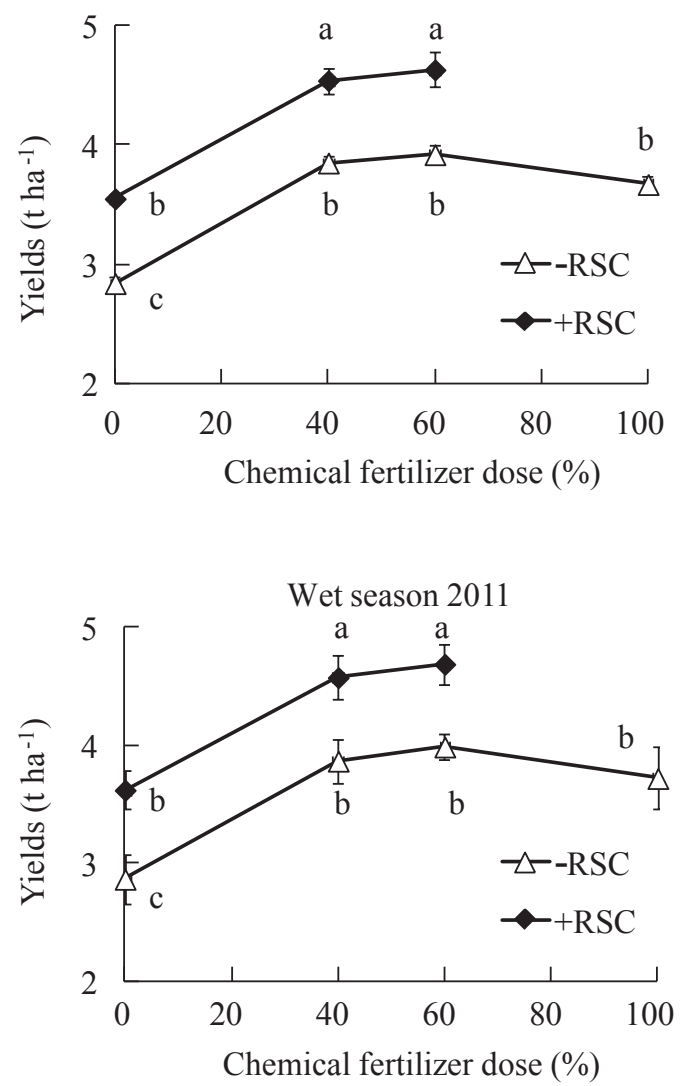

Fig. 1. Rice yields from different forms of fertilizer management Data with the same alphabet do not differ significantly (Tukey $\mathrm{p}<0.05$ ). $+\mathrm{RSC}$ and $-\mathrm{RSC}$ mean that the rice straw compost was applied and not applied, respectively.

Yield of each treatment in each crop/Yield of F100C- ${ }^{\S} \times$ $100(1)$

${ }^{\S}$ Average yield of the triplicate $\mathrm{F} 100 \mathrm{C}$ - treatment plots for each crop

The annual trends of yields relative to that of the $\mathrm{F} 100 \mathrm{C}-$ treatment, for the 4 treatments $(\mathrm{F} 0 \mathrm{C}-$, F0C + , $\mathrm{F} 40 \mathrm{C}+$, and $\mathrm{F} 60 \mathrm{C}+$ ) during the wet and dry seasons, were statistically analyzed using an Excell Tohkei 2008 (SSRI, Tokyo, Japan).

\section{Nutrient measurement in plants}

The rice straw at harvest was sampled from the 2009/2010 dry season to the 2011 wet season. The samples were dried at $70^{\circ} \mathrm{C}$ for 3 days, and ground. The $\mathrm{N}$ content was determined using an $\mathrm{NC}$ analyzer (Sumigraph NC-220F; Sumika Chemical Analysis Service, Osaka Japan). Si was solubilized using dilute hydrofluoric acid extraction, and determined using the molybdenum colorimetric method $^{16}$. The concentrations of $\mathrm{P}, \mathrm{K}, \mathrm{Ca}, \mathrm{Mg}, \mathrm{Mn}$, $\mathrm{Fe}, \mathrm{Zn}$, and $\mathrm{Cu}$ were determined using inductively coupled plasma (ICP) (ICPE-9000; Shimadzu, Kyoto, Japan), after digestion with a mixture of nitric acid and hydrogen perox- ide using a microwave digester (MIS 1200 mega; Milestone, Sorisole, Italy).

\section{Results}

The rice yields from the 2009/2010 dry season to the 2011 wet season are shown in Fig. 1. During the two wet seasons, the yields for the $\mathrm{F} 40 \mathrm{C}+$ and $\mathrm{F} 60 \mathrm{C}+$ treatments (4.54 - $4.69 \mathrm{t} \mathrm{ha}^{-1}$ ) significantly exceeded those for the other treatments. During the 2009/2010 dry season, there were no significant differences among treatments, except for the F0C - treatment. Conversely, during the 2010/2011 dry season, the yields for the F40C+ and F60C+treatment $(7.09 \mathrm{t}$ $\mathrm{ha}^{-1}$ and $7.48 \mathrm{tha}^{-1}$ ) significantly exceeded those for the F0C - , F0C + , F40C-, and F100C- treatments. Table 2 shows the yield components from the 2009/2010 dry season to the 2011 wet season. Compared with the F60C- and F100C - treatments, the filled grain (\%) for the F40C+ and F60C+ treatments for the 2010/2011 DS, 2010WS and 2011WS was higher. The 1000 grain weight for F40C+ and $\mathrm{F} 60 \mathrm{C}+$ for the 2 wet seasons was also higher than the other treatments. 
Table 2. Yield components

\begin{tabular}{|c|c|c|c|c|c|c|c|c|}
\hline & $\begin{array}{c}2009 / 2010 \\
\text { DS }\end{array}$ & $\begin{array}{c}2010 / 2011 \\
\text { DS }\end{array}$ & 2010 WS & $2011 \mathrm{WS}$ & $\begin{array}{c}2009 / 2010 \\
\text { DS }\end{array}$ & $\begin{array}{c}2010 / 2011 \\
\text { DS }\end{array}$ & 2010 WS & $2011 \mathrm{WS}$ \\
\hline \multicolumn{5}{|c|}{ Panicle number $/ \mathrm{m}^{2}$} & \multicolumn{4}{|c|}{ Spikelets/Panicle } \\
\hline F0C- & $407 \mathrm{a}$ & $386 b$ & $373 b$ & $369 b$ & $74.6 \mathrm{c}$ & $78.4 \mathrm{e}$ & $59.9 \mathrm{~d}$ & $62.5 b$ \\
\hline $\mathrm{F} 0 \mathrm{C}+$ & $427 \mathrm{a}$ & $415 \mathrm{ab}$ & $379 b$ & $380 \mathrm{ab}$ & $84.4 \mathrm{bc}$ & $84.1 \mathrm{~d}$ & $73.5 \mathrm{~cd}$ & $65.9 \mathrm{~b}$ \\
\hline F40C- & $407 a$ & $319 a b$ & $418 \mathrm{ab}$ & $413 a b$ & $97.0 \mathrm{ab}$ & $94.1 \mathrm{c}$ & $83.3 \mathrm{bc}$ & $87.6 \mathrm{a}$ \\
\hline $\mathrm{F} 40 \mathrm{C}+$ & $400 \mathrm{a}$ & $420 \mathrm{ab}$ & $448 \mathrm{a}$ & $451 \mathrm{a}$ & $97.9 \mathrm{ab}$ & $103.3 \mathrm{a}$ & $102.6 \mathrm{a}$ & $96.3 \mathrm{a}$ \\
\hline F60C- & $421 \mathrm{a}$ & $432 a$ & $414 \mathrm{ab}$ & $435 \mathrm{ab}$ & $100.3 \mathrm{a}$ & $101.6 \mathrm{a}$ & $100.7 \mathrm{a}$ & $101.3 \mathrm{a}$ \\
\hline $\mathrm{F} 60 \mathrm{C}+$ & $426 \mathrm{a}$ & $429 \mathrm{a}$ & $441 \mathrm{a}$ & $446 a$ & $104.7 \mathrm{a}$ & $102.4 \mathrm{a}$ & $105.2 \mathrm{a}$ & $104.7 \mathrm{a}$ \\
\hline F100C- & $429 \mathrm{a}$ & $435 \mathrm{a}$ & $428 \mathrm{a}$ & $428 \mathrm{ab}$ & $95.1 \mathrm{~b}$ & $98.4 b$ & $95.2 \mathrm{ab}$ & $90.2 \mathrm{a}$ \\
\hline \multicolumn{5}{|c|}{ Filled grain $(\%)$} & \multicolumn{4}{|c|}{1000 grain weight $(\mathrm{g})$} \\
\hline F0C- & $71.2 \mathrm{a}$ & $74.4 \mathrm{a}$ & $67.7 \mathrm{a}$ & $68.6 \mathrm{a}$ & $29.2 \mathrm{a}$ & $29.0 \mathrm{~d}$ & $27.4 \mathrm{c}$ & $27.5 b$ \\
\hline $\mathrm{F} 0 \mathrm{C}+$ & $72.2 \mathrm{a}$ & $74.4 \mathrm{a}$ & $67.3 \mathrm{a}$ & $68.5 \mathrm{a}$ & $29.2 \mathrm{a}$ & $29.1 \mathrm{~cd}$ & $27.6 \mathrm{bc}$ & $27.6 b$ \\
\hline F40C- & $70.5 \mathrm{a}$ & $74.3 \mathrm{a}$ & $67.1 \mathrm{a}$ & $67.4 b$ & $29.6 \mathrm{a}$ & $29.3 \mathrm{ab}$ & $27.9 \mathrm{~b}$ & $27.9 \mathrm{~b}$ \\
\hline $\mathrm{F} 40 \mathrm{C}+$ & $71.6 \mathrm{a}$ & $74.1 \mathrm{a}$ & $67.2 \mathrm{a}$ & $67.5 b$ & $29.1 \mathrm{a}$ & $29.3 \mathrm{a}$ & $28.9 \mathrm{a}$ & $28.6 \mathrm{a}$ \\
\hline F60C- & $71.8 \mathrm{a}$ & $72.2 b$ & $62.4 \mathrm{a}$ & $64.6 \mathrm{~d}$ & $29.2 \mathrm{a}$ & $29.3 \mathrm{ab}$ & $27.6 \mathrm{c}$ & $27.6 \mathrm{~b}$ \\
\hline F60C+ & $70.5 \mathrm{a}$ & $74.0 \mathrm{a}$ & $64.9 \mathrm{a}$ & $65.8 \mathrm{c}$ & $29.1 \mathrm{a}$ & $29.3 \mathrm{ab}$ & $28.9 \mathrm{a}$ & $28.8 \mathrm{a}$ \\
\hline F100C- & $71.6 \mathrm{a}$ & $71.2 \mathrm{~b}$ & $62.0 \mathrm{a}$ & $64.3 \mathrm{~d}$ & $29.3 a$ & $29.2 b c$ & $27.5 \mathrm{bc}$ & $27.5 b$ \\
\hline
\end{tabular}

Values in a column followed by the same letter do not differ significantly using a Tukey's multiple comparison $(\mathrm{P}<0.05)$. DS, dry season; WS, wet season

The relative yields for the $\mathrm{F} 0 \mathrm{C}+, \mathrm{F} 40 \mathrm{C}+$, and $\mathrm{F} 60 \mathrm{C}+$ treatments during the wet season increased significantly over time (Fig. 2). The relative yields for all of the treatments during the dry season showed no significant changes over time, probably because of abnormal results during the 2002/2003 season, when rice blast disease heavily affected the rice growth and yield; this was especially true for in the F100C-treatment, which was used as the denominator to calculate the relative yield. When the data for the 2002/2003 season were excluded (as shown in different symbol from other years in Fig. 3), significant increases in the yield over time were recorded for the $\mathrm{F} 0 \mathrm{C}-, \mathrm{F} 0 \mathrm{C}+, \mathrm{F} 40 \mathrm{C}+$, and $\mathrm{F} 60 \mathrm{C}+$ treatments .

The $\mathrm{N}, \mathrm{P}$, and $\mathrm{Mg}$ concentrations of rice straw increased in response to the chemical fertilizer dosage (Fig. 4). Conversely, the Si concentration of rice straw from the F100C - treatment plots was significantly lower than those from the $\mathrm{F} 0 \mathrm{C}+, \mathrm{F} 40 \mathrm{C}+$, and $\mathrm{F} 60 \mathrm{C}+$ treatment plots (Fig. 4). The concentrations of $\mathrm{K}, \mathrm{Ca}, \mathrm{Mn}, \mathrm{Fe}, \mathrm{Zn}$, and $\mathrm{Cu}$ did not differ significantly among treatments; therefore, only the averages and standard errors of these nutrients for each harvest are shown in Table 3.

\section{Discussion}

We observed significant increases in the relative yields over time for the $\mathrm{F} 0 \mathrm{C}+, \mathrm{F} 40 \mathrm{C}+$, and $\mathrm{F} 60 \mathrm{C}+$ treatments, in the wet and dry seasons. These results indicate a gradual decrease in soil fertility for the F100C- treatment or a gradual increase in soil fertility for the $\mathrm{F} 0 \mathrm{C}+, \mathrm{F} 40 \mathrm{C}+$, and $\mathrm{F} 60 \mathrm{C}+$ treatments. The significant increases in relative yields over time are most likely caused by repeated application of RSC.
The $\mathrm{N}$ and $\mathrm{P}$ concentrations in the rice straw increased with the fertilizer application rate (Fig. 4) but were not correlated with the yield increase. These results are in accordance with those of previous studies ${ }^{20}$. The concentrations of $\mathrm{K}, \mathrm{Ca}, \mathrm{Mn}, \mathrm{Fe}, \mathrm{Zn}$, and $\mathrm{Cu}$ did not differ significantly among treatments (Table 3), suggesting that these elements may not be limiting factors for the rice yield.

In comparison with the optimum $\mathrm{N}$ concentration range of rice straw at maturity, which is proposed by IRRI ${ }^{4}$ to be 6-8 $\mathrm{g} \mathrm{kg}^{-1}$, the $\mathrm{N}$ concentration for the $\mathrm{F} 100 \mathrm{C}-$ treatment was much higher, while those for the $\mathrm{F} 40 \mathrm{C}+$ and $\mathrm{F} 60 \mathrm{C}+$ treatments were either within the optimum range, or slightly higher. The $\mathrm{P}$ concentration for the $\mathrm{F} 100 \mathrm{C}$ - treatment was within the optimum range (1.0-1.5 $\left.\mathrm{g} \mathrm{kg}^{-1}\right)$, while those for the $\mathrm{F} 40 \mathrm{C}+$ and $\mathrm{F} 60 \mathrm{C}+$ treatments were lower. The $\mathrm{K}, \mathrm{Mg}$, and $\mathrm{Ca}$ concentrations for all treatments were close to the optimum ranges (15-20, 2-3, and 3-5 $\mathrm{g} \mathrm{kg}^{-1}$, respectively), while $\mathrm{Cu}$ concentrations for all treatments exceeded the critical level $\left(6 \mathrm{mg} \mathrm{kg}^{-1}\right)$. No optimum or critical ranges for $\mathrm{Mn}, \mathrm{Fe}$, or $\mathrm{Zn}$ are defined by IRRI. Our results indicate that farmers in the Mekong Delta can reduce N and K fertilization rate below the conventional application rates. Dobermann and Fairhurst ${ }^{4}$ showed that the critical level of Fe toxicity for young leaves, from the tillering to the panicle initiation stage, should be approximately $300-500 \mathrm{mg} \mathrm{kg}^{-1}$. Our present data regarding Fe concentrations were derived from a different growth stage; nevertheless, it is reasonable to suspect potential Fe toxicity in the field, because the $\mathrm{Fe}$ concentration ranged from 318 to $630 \mathrm{mg} \mathrm{kg}^{-1}$.

The Si concentration for the F100C- treatment, where the rice straw had been removed, was significantly lower than those for the $\mathrm{F} 0 \mathrm{C}+, \mathrm{F} 40 \mathrm{C}+$, and $\mathrm{F} 60 \mathrm{C}+$ treatments 

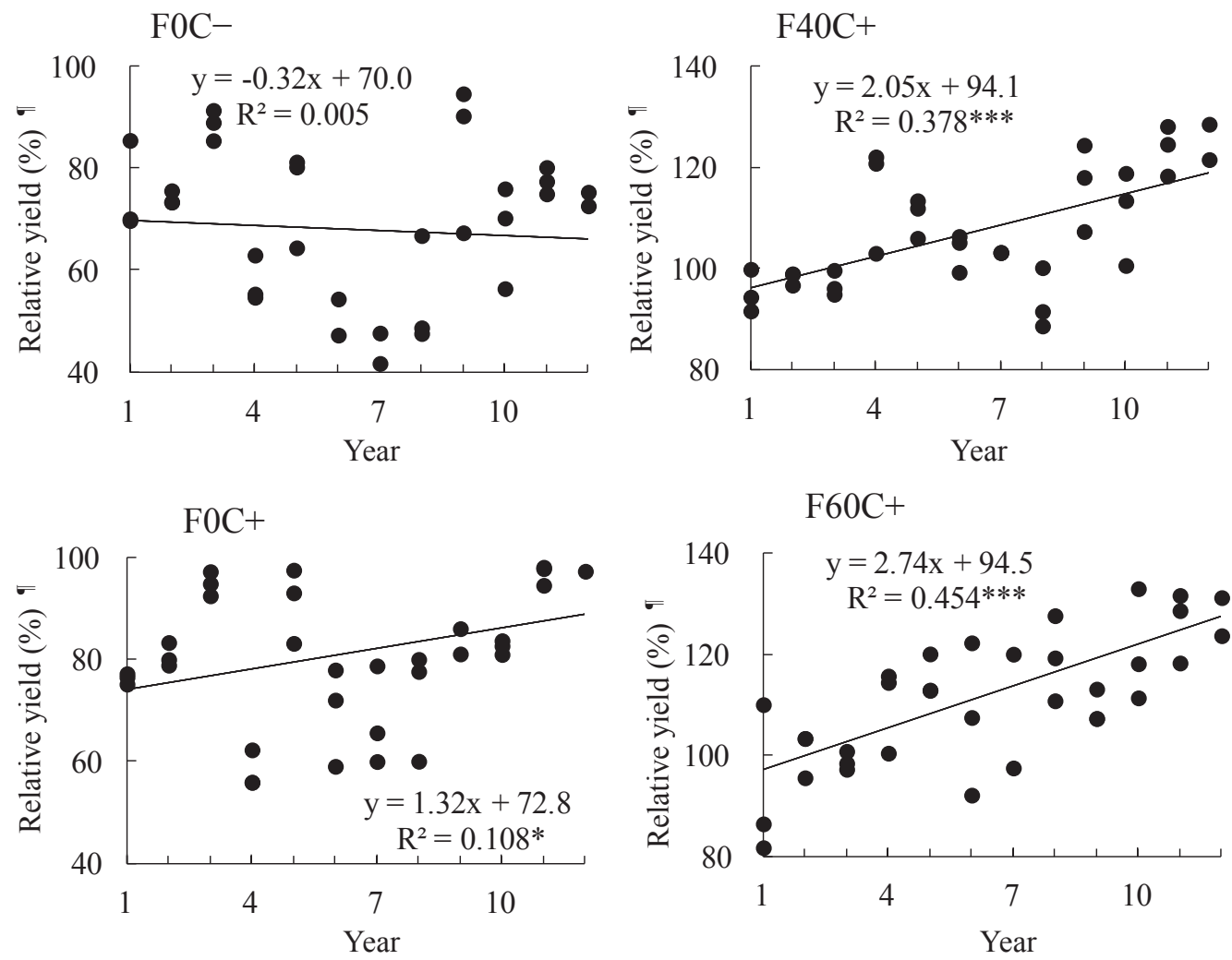

$\mathrm{F} 60 \mathrm{C}+$

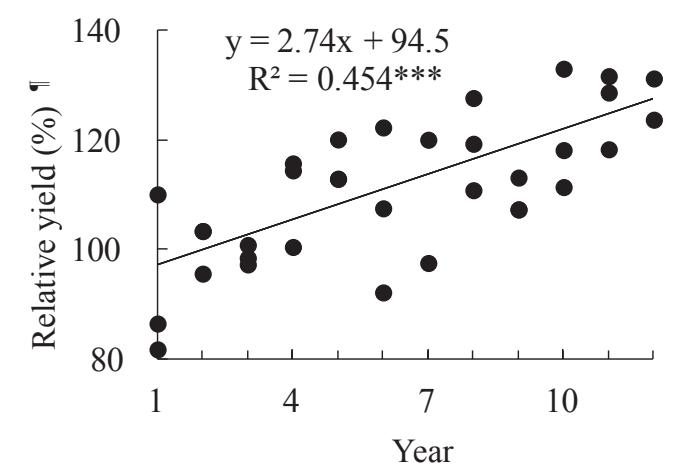

Fig. 2. Annual changes in relative yields in the wet season

I: (Yield of each treatment) / (Yield of $\mathrm{F} 100 \mathrm{C}-$ ) $\times 100$. *,** and *** means the slopes of the regression lines differed significantly from zero $(\mathrm{p}<0.05,0.01$ and 0.001 , respectively).
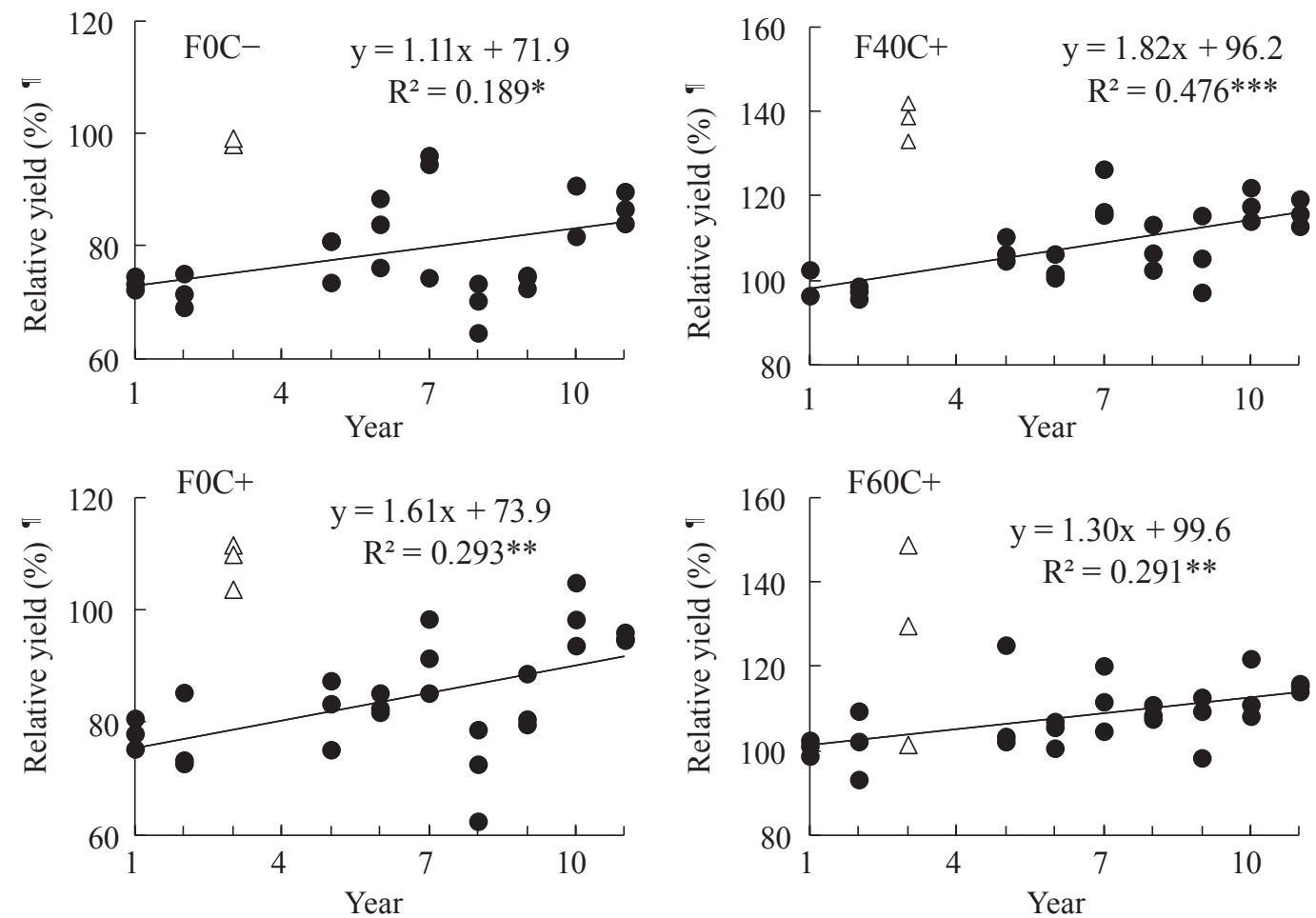

Fig. 3. Annual changes in relative yields in the dry season

T: (Yield of each treatment) / (Yield of F100C-) $\times 100$. *,** and *** means the slopes of the regression lines differed significantly from zero ( $<<0.05,0.01$ and 0.001 , respectively). Third year data (shown by $\triangle$ ) was excluded from the calculation of the regression line and the statistical test. 

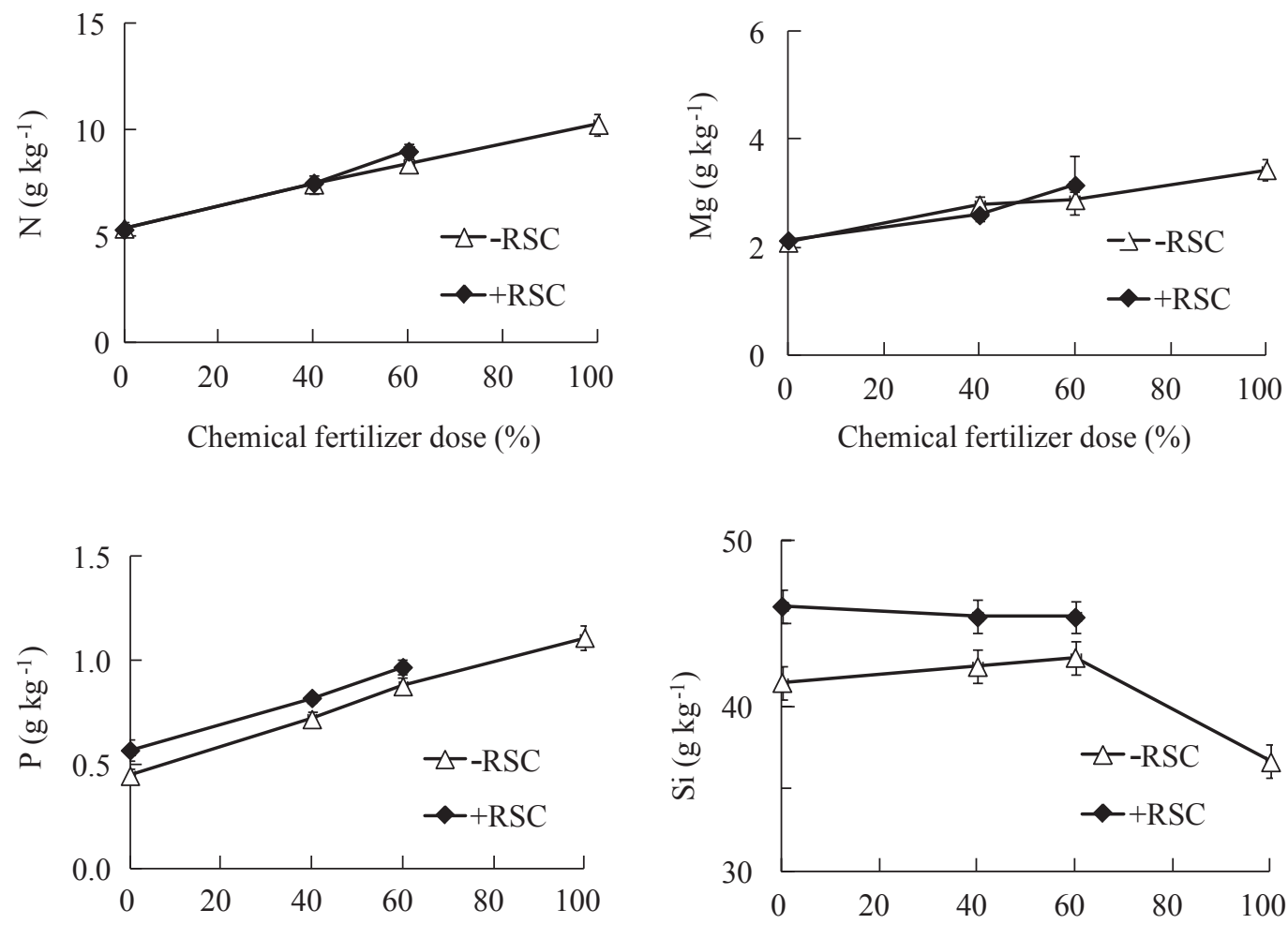

Chemical fertilizer dose (\%)

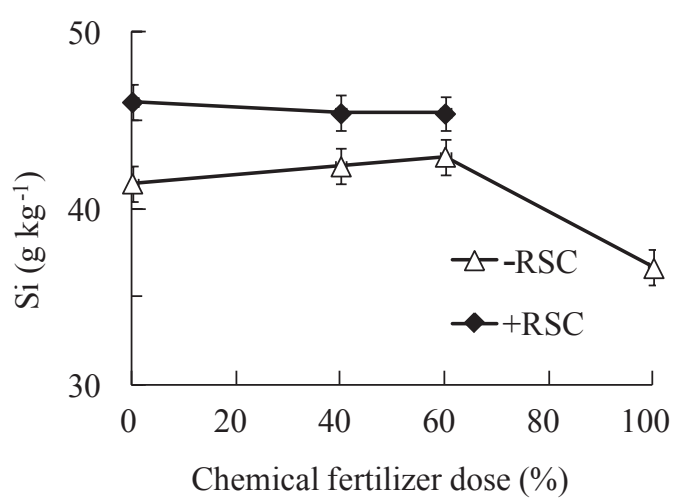

Fig. 4. Nitrogen, phosphorus, magnesium and silicon concentrations in rice straw at harvest* from the different fertilizer managements

Bars mean standard errors. +RSC and -RSC mean that the rice straw compost was applied and not applied, respectively.

*: Average of the 4 cropping seasons crops from the dry season 2009/2010 to the wet season 2011.

Table 3. Average concentrations of $\mathrm{K}, \mathrm{Ca}, \mathrm{Mn}, \mathrm{Fe}, \mathrm{Zn}$ and $\mathrm{Cu}$ in the rice straw

\begin{tabular}{cccrr}
\hline \hline & $2009 / 2010 \mathrm{DS}$ & $2010 / 2011 \mathrm{DS}$ & $2010 \mathrm{WS}$ & $2011 \mathrm{WS}$ \\
\hline $\mathrm{K}\left(\mathrm{g} \mathrm{kg}^{-1}\right)$ & $21(0.39)$ & $17(0.32)$ & $17(0.38)$ & $16(0.22)$ \\
$\mathrm{Ca}\left(\mathrm{g} \mathrm{kg}^{-1}\right)$ & $4.9(0.17)$ & $4.0(0.18)$ & $3.3(0.06)$ & $3.6(0.18)$ \\
$\mathrm{Mn}\left(\mathrm{mg} \mathrm{kg}^{-1}\right)$ & $600(14)$ & $718(29)$ & $769(29)$ & $611(35)$ \\
$\mathrm{Fe}\left(\mathrm{mg} \mathrm{kg}^{-1}\right)$ & $377(14)$ & $630(40)$ & $488(29)$ & $318(16)$ \\
$\mathrm{Zn}\left(\mathrm{mg} \mathrm{kg}^{-1}\right)$ & $32(0.8)$ & $32(0.8)$ & $37(0.9)$ & $31(1.0)$ \\
$\mathrm{Cu}\left(\mathrm{mg} \mathrm{kg}^{-1}\right)$ & $22(1.6)$ & $17(0.8)$ & $16(1.2)$ & $11(0.5)$ \\
\hline
\end{tabular}

Standard errors are shown in brackets. DS, dry season; WS, wet season.

(Fig. 4). As mentioned previously, the low yield for the F100C - treatment during the 2002/2003 dry season, which was caused by rice blast disease, increased the relative yields of the remaining treatments and distorted the annual yield trends. The higher $\mathrm{N}$ and lower Si concentrations of the rice straw for the $\mathrm{F} 100 \mathrm{C}$ - treatment appear to have made the rice more susceptible to rice blast disease ${ }^{8,24}$. Sumida $^{18}$ reported that $\mathrm{Si}$ contents of rice leaf blades were negatively correlated with $\mathrm{N}$ contents. As a consequence of higher $\mathrm{N}$ application, and the continuous removal of rice straw without RSC application, an imbalance between N and $\mathrm{Si}$ for the $\mathrm{F} 100 \mathrm{C}$ - treatment may have led to increases in relative yields over time for the $\mathrm{F} 0 \mathrm{C}+, \mathrm{F} 40 \mathrm{C}+$, and $\mathrm{F} 60 \mathrm{C}+$ treatments. The filled grain (\%) and 1000 grain weight of the $\mathrm{F} 100 \mathrm{C}$ - treatment tended to be lower than those of the $\mathrm{F} 40 \mathrm{C}+$ and $\mathrm{F} 60 \mathrm{C}+$ treatments (Table 2). The lower yields for the $\mathrm{F} 40 \mathrm{C}$ - and $\mathrm{F} 60 \mathrm{C}$ - treatments in comparison with the $\mathrm{F} 40 \mathrm{C}+$ and $\mathrm{F} 60 \mathrm{C}+$ treatments (Fig. 1) suggest that this imbalance cannot be corrected solely by adjusting the $\mathrm{N}$ fertilizer application rate.

Although not generally considered an essential element, $\mathrm{Si}$ is often beneficial for rice $\mathrm{e}^{1,9,12}$. The Si concentrations of our rice straw (average $42.9 \mathrm{mg} \mathrm{kg}^{-1}$ ) were lower than the critical concentration $\left(<50 \mathrm{mg} \mathrm{kg}^{-1}\right)^{4}$ and also the 
typical concentrations reported in Japan ${ }^{5}$. Si has been reported as playing an important role in rice growth, but its physiological functions remain poorly understood. Si is known to be required to develop strong leaves, stems, and roots. The formation of a thick silicated epidermal cell layer reduces the susceptibility of rice plants to fungal and bacterial diseases ${ }^{8}$, and also to insects (stem borers, plant hoppers) and mite pests. Rice plants with an adequate supply of Si have erect leaves, which boosts dry matter production through more efficient radiation and $\mathrm{N}$ use $\mathrm{e}^{1,4}$.

Recently, phytoliths have been considered a major source of Si available to plants. It is shown by a long-term trial conducted at Rothamsted Experimental Station that the annual straw exports from wheat fields reduce the amount of phytolith input to the soil, which decreases the bio-available Si in soils. A significant correlation between Si concentration in straw and yield is also shown ${ }^{7}$. In a long-term trial with rice conducted at four experimental stations located in northern Japan, it was shown that the plant-available $\mathrm{Si}$ in the surface soil with continuous rice straw application was 1.25 times higher than without the application ${ }^{10}$. Savant et al. ${ }^{17}$ suggests that the depletion of plant-available $\mathrm{Si}$ in paddy soils could be a possible limiting factor contributing to the declining yields often observed in continuous rice cropping area worldwide.

Because phytoliths remain in soil long-term, it was thought that rice straw might not effectively supply Si for the following crops. Anzai ${ }^{2}$ confirmed that rice straw ash supplied more Si than rice straw compost for paddy rice under field conditions. However, Wickramasinghe and Rowel1 ${ }^{22}$ demonstrated that rice straw added to soil suspensions increased the silicon concentration during incubation. Phutela and Sahni ${ }^{15}$ showed that fungi promotes the solubilization of silica components in rice straw.

Dawe et al. ${ }^{3}$ analyzed yield trends in 7 long-term experiments in Asia, with the rice cultivated twice a year, and concluded that the application of manure or straw failed to improve yield trends. The results of our present study contradict this conclusion. Watanabe et al. ${ }^{20}$ reported the significant effect of RSC application on soil physical properties. RSC application was shown to maintain soils in a softer state, i.e. with a lower bulk density, than that of soils without RSC. However, the increase in relative yields for the $\mathrm{F} 0 \mathrm{C}+, \mathrm{F} 40 \mathrm{C}+$, and $\mathrm{F} 60 \mathrm{C}+$ treatments in our present study may not have been caused exclusively by organic matter amendment. If the relative yield trend in our present study was caused by a decrease in available Si for the F100C - treatment, it may be possible to compensate for this by applying Si using a chemical fertilizer. Further studies to clarify the effect of Si application are required.

Collectively, our results suggest that continuous removal of rice straw may reduce the Si availability in soil, thereby decreasing rice productivity. Although this causal relationship remains to be confirmed, our results indicate that, in comparison with the conventional fertilization, application of RSC with reduced chemical fertilizer can maintain rice productivity over a longer period. In addition, we verified that rice straw compost could be an effective source of silicon for paddy rice.

\section{Acknowledgments}

We thank the late Mr. Satoru Miyata for his support during our experiment. We are also grateful to Dr. Kanwar Sahrawat for his invaluable advice.

\section{References}

1. Ando, H. et al. (2002) Growth and canopy structure of rice plants grown under field conditions as affected by Si application. Soil Sci. Plant Nutr., 48, 429-432.

2. Anzai, T. (1993) Effect of successive application of organic matter on the cultivation of paddy rice in grey paddy soil, III. Influence of successive application of rice straw ash on growth, yield and nutrient uptake of paddy rice and on chemical properties of paddy soil. Bull.Chiba.Agric.Exp.Sta., 34, $12-21$.

3. Dawe, D. et al. (2003) Do organic amendments improve yield trends and profitability in intensive rice system? Field Crops Res., 83, 191-213.

4. Dobermann, A. \& Fairhurst, T. (2000) Nutrient disorders and nutrient management, International Rice Research Institute, Potash \& Phosphate Institute and Potash \& Phosphate Institute of Canada, Macaty City, Philippines (This book is distributed in the form of CD-ROM).

5. Fujii, H. (2002) Effect of silicate on growth, yield and taste of rice, in Japanese society of soil science and plant nutrition. (Eds.), Silicon and crop production. Hakuyu-sha, Tokyo, pp. 41 [In Japanese].

6. General Statistics Office Vietnam (2005) Statistical Yearbook 2004. Statistical publishing house, Hanoi. pp. 159.

7. Guntzer, F. et al. (2012) Long-term removal of wheat straw decreases soil amorphous silica at Broadbalk, Rothamsted. Plant. Soil, 352, 173-184.

8. Hayasaka, T. et al. (2008) The role of Silicon in preventing appressorial penetration by the rice blast fungus. Phytopathol., 98, 1038-1044.

9. Heinai, F. et al. (2005) Effect of application porous hydrate calcium silicate and porous hydrate calcium silicate on the growth of rice plants (Oryza sativa L.). Soil Sci. Plant Nutr., 51, 961-966.

10. Kobayashi, N. (2006) Effect of long-term application of rice straw on the plant available silicon of paddy soil. Proceedings of the $18^{\text {th }}$ World Congress of Soil Science, July 9-15, Philadelphia, Pennsylvania, USA.

11. Kyuma, K. (1985) Fundamental Characteristics of Wetland Soils. Proc. of Wetland Soils Workshop. IRRI, 191-206.

12. Mori, S. \& Fujii, H. (2009) Effectiveness of silica application at the panicle formation stage on the rice production. Jpn. J. Soil Sci. Plant Nutr., 80, 136-142 [In Japanese with English summary].

13. National Institute for Soils and Fertilizers \& Department of 
Science, Technology and Product Quality (2002) The basic information of main soil units of Vietnam. Thegioi publishers, Hanoi, 60-63.

14. Pham S. T. et al. (1995) Yield trends of a long-term NPK experiment for intensive rice monoculture in the Mekong River Delta of Viet Nam. Field Crops Res., 42, 101-109.

15. Phutela, U. G. \& Sahni, N. (2012) Microscopic structural changes in paddy straw pretreated with Tricoderma reesei MTCC 164 and Coriolus versicolor MTCC 138. Indian J. Microbiol., DOI 10.1007/212088-012-0321-8.

16. Saito, K. et al. (2005) Rapid, micro-methods to estimate plant silicon content by dilute hydrofluoric acid extraction and spectrometric molybdenum method. Soil Sci. Plant Nutr., 51, 29-36.

17. Savant, N.K. et al. (1997) Silicon management and sustainable rice production. Adv. Agron., 58, 151-199.

18. Sumida, K. (1992) Effects of nitrogen nutrition on silica uptake by rice pant. Jpn. J. Soil Sci. Plant Nutr., 63, 633-638 [In Japanese with English summary].

19. Tran, Q.T. et al. (2006) Influence of long term application of
N, P, K fertilizer on major soil elements. Omonrice, 14, 92-96.

20. Watanabe, T. et al. (2009) Effects of continuous rice straw compost application on rice yield and soil properties in the Mekong Delta. Soil Sci. Plant Nutr., 55, 754-763.

21. Watanabe, T. \& Sumida, H. (2009) Experiment on the replicated rice straw compost application on paddy field and remediation of degraded environment on acid sulfate soil in the Mekong Delta. Jpn. J. Soil Sci. Plant Nut., 80, 288-296 [In Japanese].

22. Wickramasinghe D. B. \& Rowell, D. L. (2006) The release of silicon from amorphous silica and rice straw in Sri Lankan soils. Biol. Fertil. Soils, 42, 231-240.

23. Yoshida, S. (1981) Fundamentals of rice crop science, The International Rice Research Institute, Los Banos, Laguna, Philippines.

24. Yoshino, R. (1987) Epidemiology of rice blast disease. In Rice blast disease, eds. Yamanaka, S. \& Ymaguchi, T., Yokendo, Hakuyu-sha, Tokyo, pp. 112 [In Japanese]. 